\title{
Using Landfill Gas for Energy: \\ Projects that Pay
}

\section{Pending Environmental Protection Agency regulations will require 500 to 700 landfills to control gas emissions resulting from decomposing garbage. Conversion of landfill gas to energy not only meets regulations, but also creates energy and revenue for local governments.}

How often is a local government able to make money through compliance with health and environmental regulations? How often does a development project result in less pollution than the "no project" alternative?

In many parts of the country, cities and counties are experiencing such successes by using landfill gas (LFG) to produce electricity, heat, or steam for industrial use. Local governments are finding out that.LFG use can supply energy, generate significant

ironinental Protection Agency regulations. Converting the gas to energy can produce revenue while eliminating liabilities.
DISTAIBUTIION QF TFIIS DOCUMENT IS UNLIMITED

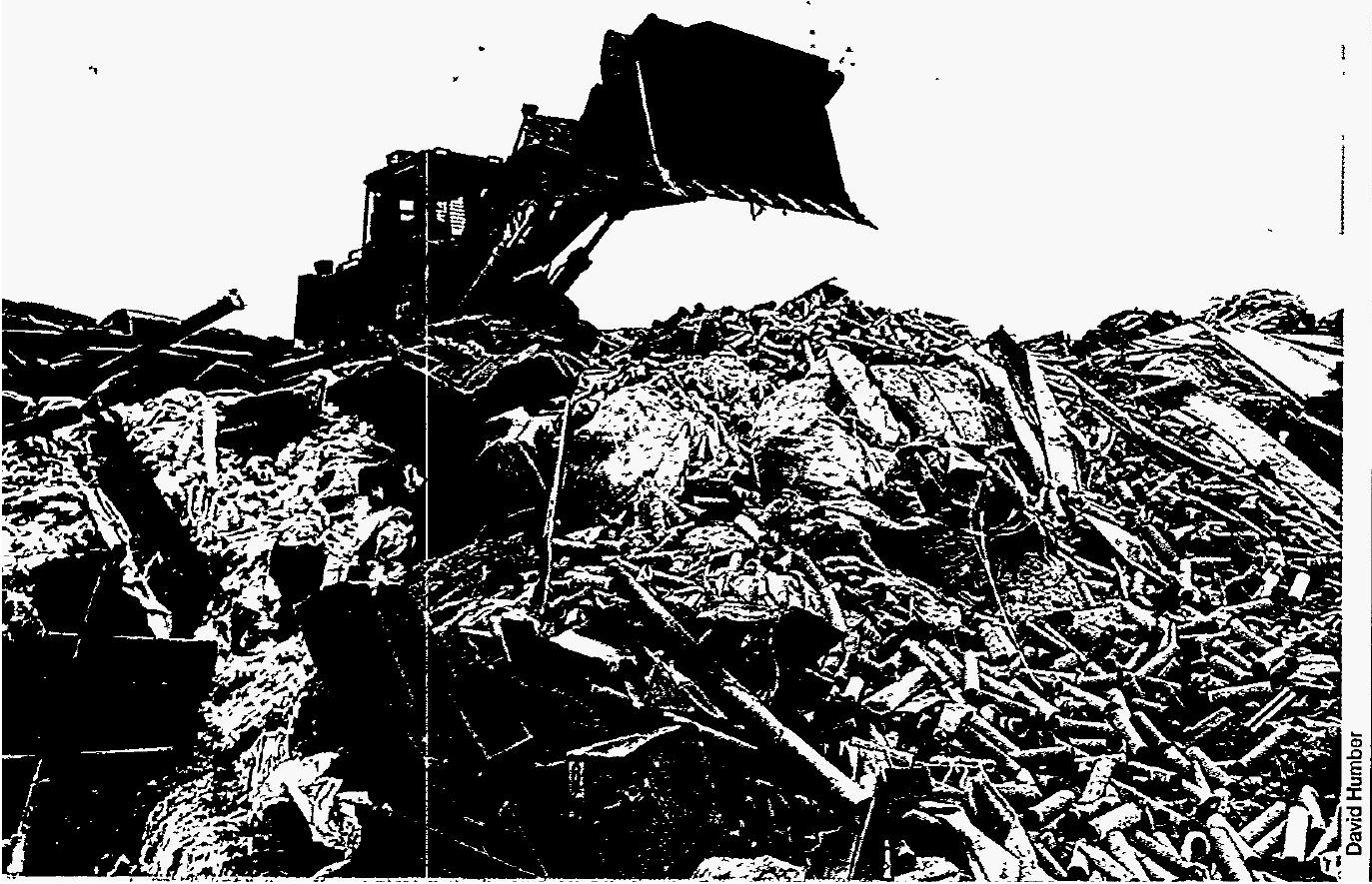

revenues, and reduce electrical demand for local utilities, delaying the need for building new power plants.

These projects consume gases that, if not collected, pose serious odor, safety, and environmental hazards. Methane, the main energy component of LFG, is a particularly potent "greenhouse" gas, having roughly 21 times the global warming effects of carbon dioxide (see Note 1, p. 6). Methane is also highly explosive and has been responsible for 40 landfill fires and explosions that resulted in 10 deaths (see Note 2, p. 6). LFG emissions contribute to local smog and can cause unpleasant odors and trigger complaints from neighbors. At the same time, LFG is considered a medium-British thermal unit (Btu) gas and can produce energy and associated revenues.

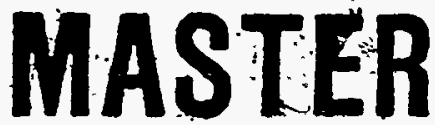




\section{DISCLAIMER}

Portions of this document may be illegible in electronic image products. Images are produced from the best available original document. 
Rhode Island: Privatization Yields Royalties for Local Government

As environmental manager at Rhode Island's publicly run Central Landfill, Dennis aRusso gets paid to worry. $\mathrm{He}$ also pays contractors to worry for him. But one company takes away a big worry and pays him.

aRusso works for the Rhode Island Solid Waste Management Corporation (RISWMC), a state-chartered entity responsible for managing Central Landfill. He is responsible for all environmental monitoring and compliance at the 154-acre (62.3-hectare) site, which receives $90 \%$ of the state's garbage. It's obvious from speaking with aRusso why he worries about environmental impacts. "I'm a third generation Johnston, Rhode Island, resident," he says. "As a kid, I played in the fields and streams around here. I care about this place."

But in the early 1980 s, residents from the nearby town of Johnston began to complain about odors from the landfill. RISWMC hired a private company to study gas flow at the landfill and the feasibility of using the gas to generate electricity for profit. The results were promising, particularly to Northeast Landfill Power Joint Venture, a local developer. In 1989, the company completed construction of an LFG-to-electricity facility.

Now, the facility captures the landfill gas to supply as much as 12.3 megawatts of electrical power, enough capacity to serve roughly 17,000 households. The company sells this electricity to a local subsidiary of New England Power and pays RISWMC \$50,000 per month in royalties for the rights to the gas. facility at a public landfill in Rhode Island produces as much as 12.3 megawatts of electricity, enough capacity to serve 17,000 households.
The public entity has zero risk on the project and has no involvement other than saving gas collection and control costs and collecting royalties of more than half a million dollars per year.

aRusso appreciates the project's revenues, but particularly values the fact that he is already complying with the new federal Environmental Protection Agency (EPA) landfill emissions regulations.

"There's no reason to have a landfill and not recover the gas," aRusso summarizes. "It's a huge advantage-it's positive all the way around."

\section{Medium-Scale Facilities Work, Too}

Lane County, Oregon, stretches from the Cascade Mountains to the Pacific Ocean and includes the cities of Eugene and Springfield. The region's natural beauty is not lost on its residents. "The people here have always been environmentally concerned and knowledgeable," says Ellie Dumdi, Lane County Commissioner.

This environmental perspective was growing in the early 1980s, when the county began exploring the possibility of an LFG-to-electricity facility at its Short Mountain Landfill. In 1985, the county issued a Request for Proposals for facility construction and operation. The Emerald People's Utility District, a local consumerowned utility serving the county's rural areas, won the contract. The LFG-to-electricity facility began operating in 1992.

The facility generates 1.6 megawatts of electrical power, enough for about 800 homes, and will increase its capacity to 4 megawatts by 2010 .
Using LFG as its fuel source, the project converts a potential pollutant into a useful product, reduces environmental control costs, and creates revenue for RISWMC in the process. 
Emerald makes roughly $1 \$$ per kilowatt-hour profit on the electricity it sells to the Bonneville Power Administration. This is basically the difference between $4.5 \$$, which is Bonneville's alternative cost of producing electricity, and 3.5\$, which is Emerald's cost to produce electricity. Emerald's total 1992 revenues were about $\$ 150,000$. Lane County receives a minimum royalty of $\$ 15,000$ per year and avoids having to build and operate an expensive collection system.

"With all of the rising landfill gas regulations, the county would have to learn a whole new business if we weren't here," says Alan Zelenka, Power Resource Specialist for Emerald. "It's a lot nicer to have someone else do all this."

\section{Mike Turner, Solid Waste Division} Manager for Lane County, agrees. "It's a win-win situation. The win for us is that we don't have to develop a gas control project. The primary benefit for the entire community is that a resource is not being lost."

Revenue from the project helps keep Emerald's rates stable, and because Emerald is a consumer-owned utility, the benefits are passed directly on to the consumers.

\section{Direct Use of Landfill Gas}

Landfill gas has a medium-Btu rating, and with minimal cleaning, can be used directly in boilers to create steam for industrial uses. This application reduces dependency on fuel oil, which is a standard fuel for boilers. Direct use does not require large capital investments for equipment such as generators and is probably the most cost-effective application of landfill gas.

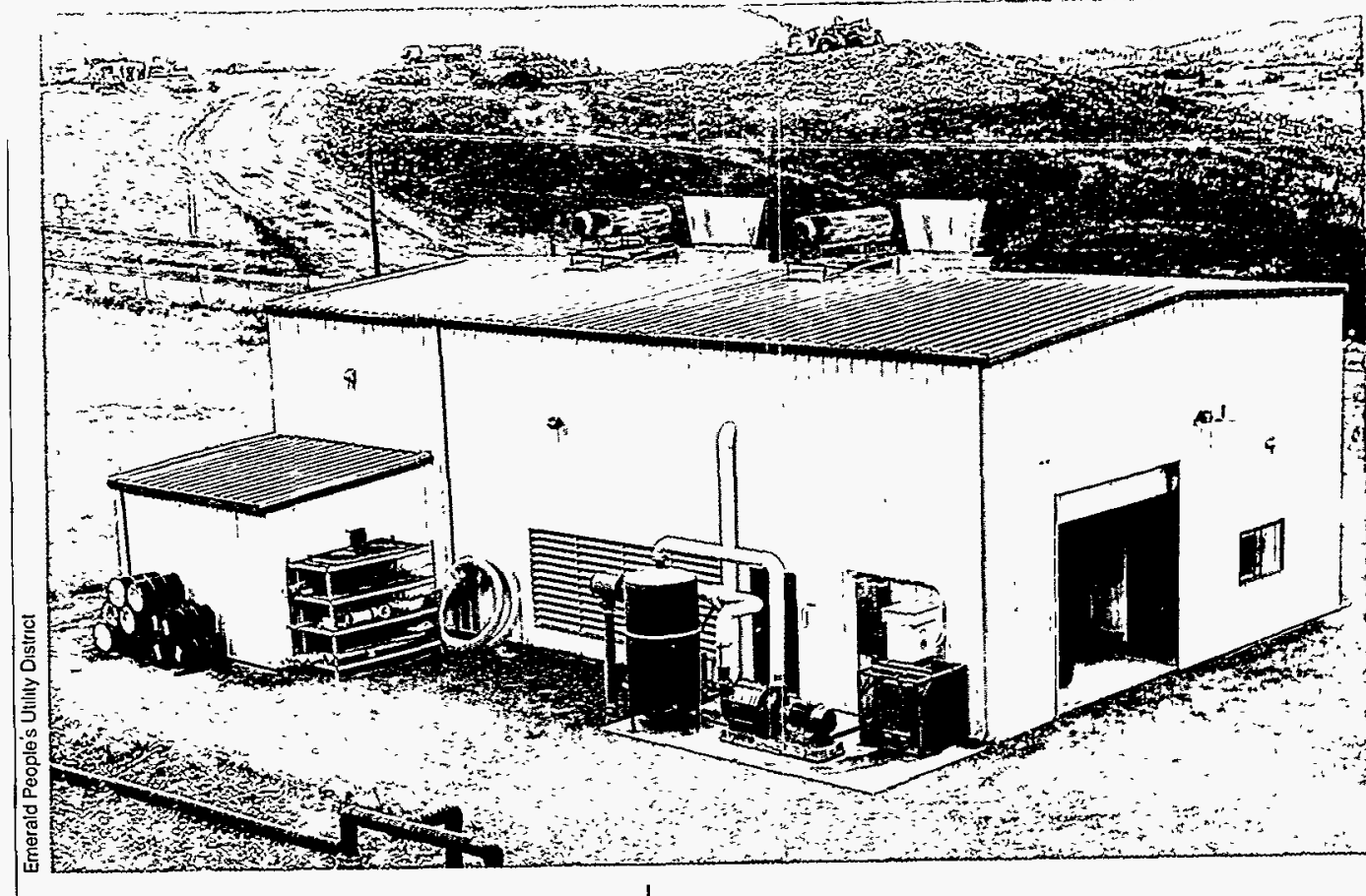

This landfill gas-to-electricity project in Oregon creates revenue for the local government and keeps the local consumer-owned utility's rates stable, thereby benefiting rate payers.

In Raleigh, North Carolina, a boiler fueled by landfill gas generates steam at an average rate of 24,000 pounds (11,000 kilograms) per hour to meet the needs of a pharmaceutical plant. The energy conversion system uses gas collected from the city-owned Wilder's Grove Landfill. The private developers, Natural Power, Inc. and Raleigh Landfill Gas Corporation, invested $\$ 1.6$ million in the project. The developers' annual gross revenue from steam sales ranges from $\$ 450,000$ to $\$ 500,000$, of which the city of Raleigh receives annual royalties of $\$ 65,000$ to $\$ 75,000$.

The project won the 1993 North Carolina Governor's Energy Achievement Award and is being considered for an Energy Innovation Award from the U.S. Department of Energy.

Marshall Ashcraft, Budget and Management Analyst in the Raleigh City Manager's Office, says, "We've created an asset out of a potential liability. This is an excellent example of public-private partnership."

\section{New Regulations}

EPA estimates that 500 to 700 landfills across the country will be affected by its pending regulations. In 1991, EPA designated "municipal solid waste landfill emissions" as a pollutant and subsequently proposed Clean Air Act emission guidelines for existing landfills and New Source Performance Standards for new landfills. The new EPA regulations will limit the volatile organic compounds in landfill gas emissions. These compounds interact with nitrous oxides to form ozone, a primary cause of smog.

Susan Thornloe, the senior project engineer responsible for EPA's research program on landfill methane, says, "We hope that the sites affected by [the new] regulations will utilize the gas as opposed to flaring it [burning off the gas in the open air, with no energy recovery]. Converting the gas to salable steam or electricity can help offset the cost of the collection and control system, and, with the right market and revenues, may be a less costly solution than just flaring the gas."

Another set of EPA regulations affects landfill gas emissions. Subtitle D of the Resource Conservation and Recovery Act, issued in October 1993, 
consists of broad-ranging regulations for landfills, including control of offsite migration of methane. Subtitle D requires control measures to prevent soil concentrations of methane higher than $5 \%$, the lower explosive limit for methane, at the site boundary. These control measures can include active (pumped) gas recovery systems suitable for commercial use.

Although several hundred landfills may be affected by new LFG regulations, there are currently only 108 fully commercial projects that sell energy to users. In addition, thousands of closed landfills could be commercially exploited for their LFG. The percentage of landfills with commercial methane recovery is low because there has been little research on, and quantification of, gas generation in actual field settings. Potential financial sector investors must often rely on very general information. As with any prospective investment, imprecise information is a hindrance.

\section{Promising Research}

The U.S. Department of Energy funds research on landfill gas with the goal of overcoming barriers to commercialization. In one study, researcher Jean Bogner, of the U.S. Department of Energy's Argonne National Laboratory, is researching LFG gas generation, migration, and emissions. A field study in California is addressing the "landfill methane balance" that is, how methane generated by micro-organisms is partitioned into: (1) methane recoverable by a commercial system, (2) methane emitted into the atmosphere, (3) methane migrated laterally, and (4) methane converted to carbon dioxide by bacteria in landfill cover material.

"Our LFG projects are practically oriented and field-based, to achieve better understanding of landfill gas processes and develop useful techniques for monitoring those processes

\section{Expanded Federal Government Landfill Gas Programs}

The following expansions to federal landfill gas (LFG) programs are being instituted as part of President Clinton's Global Climate Change Action Plan.

The U.S. Department of Energy (DOE) is charged with expanding research, development, and demonstration (RD\&D) of technologies to recover and use methane from landfills. The DOE program will:

- Develop a practical guide to assist public and private landfill owners in the design, construction, implementation, and operation of successful LFG recovery and utilization programs.

- Develop and demonstrate efficient and economic processes for increasing the recovery of energy from landfills, thereby decreasing U.S. dependence on nonrenewable energy sources.

- Create joint cooperative RD\&D projects between federal, state, industry, and other stakeholders to remove technical impediments and other barriers to implementation of enhanced LFG recovery and utilization programs.
The U.S. Environmental Protection Agency (EPA) is responsible for developing an expanded Landfill Methane Outreach Program to encourage landfill owners to capture methane that would otherwise be emitted and use it to produce electricity or sell it as a medium-Btu gas. The EPA outreach program will:

- Operate a telephone assistance service for questions regarding collection, control, and utilization of LFG.

- Provide sample requests for proposals (RFPs) to landfill owners/operators, utilities, state regulators, and others who can use these samples in starting up LFG collection and utilization projects.

- Release a case study report on landfill successes to raise awareness of emission reduction potential.

- Organize a series of state and regional workshops on landfill energy recovery opportunities.

- Initiate site visits to develop feasibility analyses of project opportunities. in field settings," says Bogner.

"There are two bottom lines for landfill owners and operators. First, if they're going to have to collect and control LFG, then it's worth looking for a customer to whom energy may be sold. And secondly, in the case of landfills that are now closed, it's still worth it because they'll be doing 30 years of postclosure monitoring and control. If they can find a customer for the gas, they can offset part, and quite possibly a good percentage, of their costs.

"With the vast number of existing landfills, more consideration should be given to direct use of LFG in gas-fired boilers near landfill sites. Existing commercial projects of this type include oil refineries, foodprocessing plants, brickworks, or other energy-intensive industries; hotel or hospital complexes; junior colleges; and greenhouses."

\section{Conclusion}

Federal LFG regulations, expected to be issued sometime in 1994, will require many landfills across the country to collect and control LFG emissions. There is a good chance your landfill district may have to install an LFG collection system. Furthermore, an LFG installation in your community may qualify for a \$.015 per kilowatt-hour Renewable Energy Production Incentive (Section 212) under the federal Energy Policy Act of 1992. Contact EPA's Resource Conservation and Recovery Hotline listed in For More Information for details about this incentive.

In the right situation, using LFG not only offsets the cost of installing a gas collection and control system, but creates significant sources of revenue. So, why not generate income for your city or county and reap the benefits of landfill gas? 


\section{Typical Landfill Gas-to-Electricity Facility}

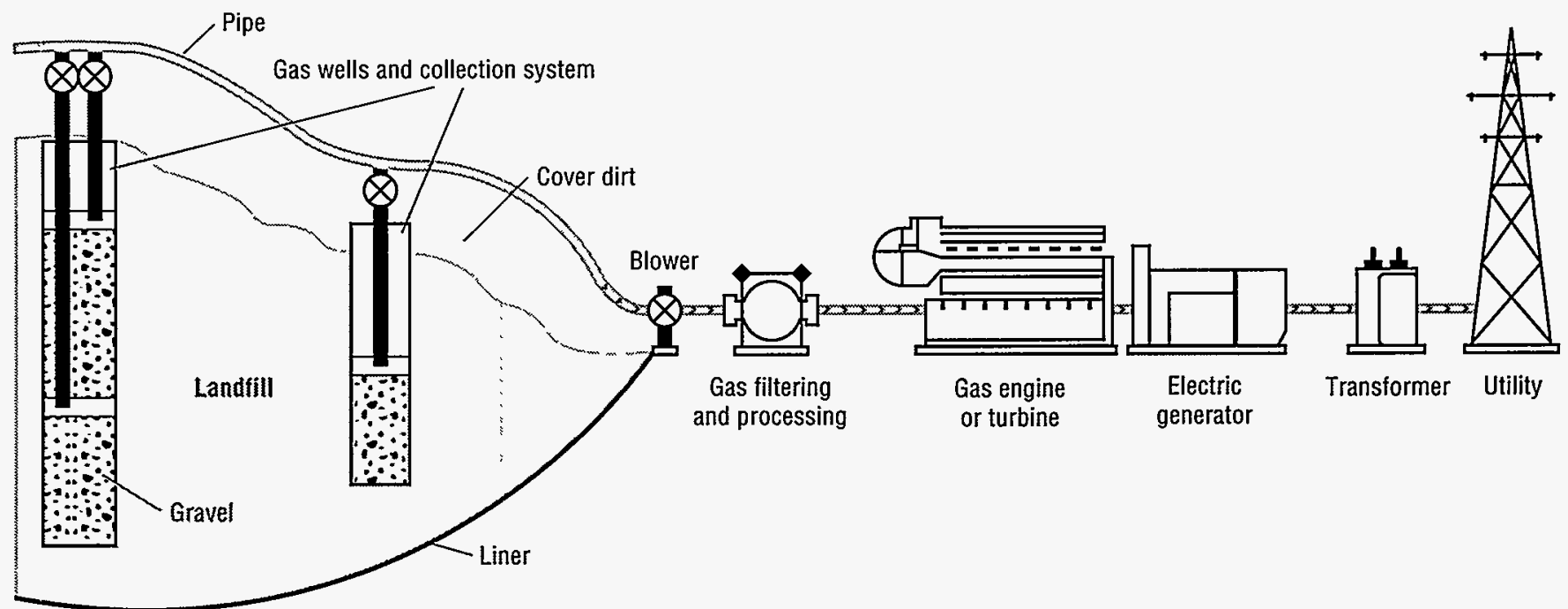

Interconnection

\section{How Landfill Gas to Electricity Works}

The most common use of landfill gas (LFG) is for on-site electricity generation. There is little difference between an electric generating plant using landfill gas and one using natural gas or diesel fuel, aside from the need for more extensive gas processing and more careful monitoring of equipment because of the potentially corrosive nature of landfill gas.

An LFG-to-electricity system has three basic components: (1) the gas collection system, which gathers the gas being produced within the landfill, (2) the gas processing and conversion system, which cleans the gas and converts it into electricity, and (3) the interconnection equipment, which delivers the electricity from the project to the final user.

\section{Gas Collection}

Gas is typically collected by a series of wells strategically placed throughout the landfill, as gas from decomposing garbage exists at all levels of the landfill. The number and spacing of wells depend on specific landfill aspects such as volume, density, and geometry.
Wells are constructed by drilling holes into the landfill, to within 5 to 15 feet ( 2 to 5 meters) from the bottom.

Perforated plastic pipes are inserted into the wells. The area around the pipes is filled with large gravel to prevent refuse from plugging the perforations. Horizontal underground trenches can also be used to recover LFG as layers of the landfill are added.

The wells are connected by a series of pipes leading to larger, header pipes that deliver the gas to the processing and conversion stations. The entire piping system is under a partial vacuum created by blowers or fans at the processing station, causing landfill gas to migrate toward the wells.

\section{Gas Processing}

Once blowers or fans deliver the gas to a central point, it can be processed or converted to another energy form. At a minimum, the gas needs to be filtered to remove any particles and condensate that may be suspended in the gas stream. After moisture removal, additional gas processing may involve the use of refrigerators or absorbers, such as activated carbon filters, to remove trace contaminants.

\section{Conversion Equipment}

Either internal combustion engines or turbines can be used to power on-site generators, which convert the gas into salable electricity.

\section{Interconnection with Utilities}

After the gas is converted to electricity, a dedicated line is used to deliver the electricity to utilities. Interconnection usually includes metering equipment necessary to monitor sales and system protection equipment with emergency shutdown capability to prevent either party from damaging the other's equipment, or operations, or injuring personnel. 


\section{For More Information}

Jean Bogner

Argonne National Laboratory

9700 South Cass Avenue

Argonne, IL 60439

(708) 252-3359

Carlton Wiles

Municipal Solid Waste

Management Program

- National Renewable Energy Laboratory

1617 Cole Boulevard

Golden, CO 80401-3393

(303) $275-2915$

Susan Thornloe

Global Emissions and Control Division

Air and Energy Engineering Research

Laboratory (MD-63)

U.S. Environmental Protection Agency

Research Triangle Park, NC 27711

(919) 541-2709

\section{DOE Regional Support Offices}

The DOE Office of Energy Efficiency and Renewable Energy reaches out to the states and private industry through a network of regional support offices. Contact your DOE regional support office for information on energy efficiency and renewable energy technologies.

\section{Atlanta DOE Support Office}

730 Peachtree Street NE, Suite 876

Atlanta, GA 30308

(404) $347-2837$

(AL, FL, GA, KY, MS, NC, PR, SC, TN;

Territory: VI)

Boston DOE Support Office

One Congress Street, 11th Floor

Boston, MA 02114

(617) $565-9700$

(CT, MA, ME, NH, RI, VT)

Chicago DOE Support Office

9800 South Cass Avenue

Argonne, IL 60439

(708) 252-2000

(IL, IN, MI, MN, OH, WI)

Dallas DOE Support Office

1420 West Mockingbird Lane, Suite 400

Dallas, TX 75247

(214) $767-7245$

(AR, LA, NM, OK, TX)

Denver DOE Support Office

2801 Youngfield Street, Suite 380

Golden, CO 80401

(303) 231-5750

(CO, MT, ND, SD, UT, WY)
Cindy Jacobs

Landfill Methane Outreach Program

Global Change Division (6202 J)

U.S. Environmental Protection Agency

401 M Street, SW

Washington, DC 20460

(202) 233-9042

EPA's Resource Conservation and

Recovery Act Hotline

(800) $424-0346$

EREC

P.O. Box 3048

Merrifield, VA 22116

(800) 363-3732

The Energy Efficiency and Renewable Energy Clearinghouse (EREC) is a service funded by the U.S. Department of Energy to provide information on renewable energy and energy efficiency technologies.

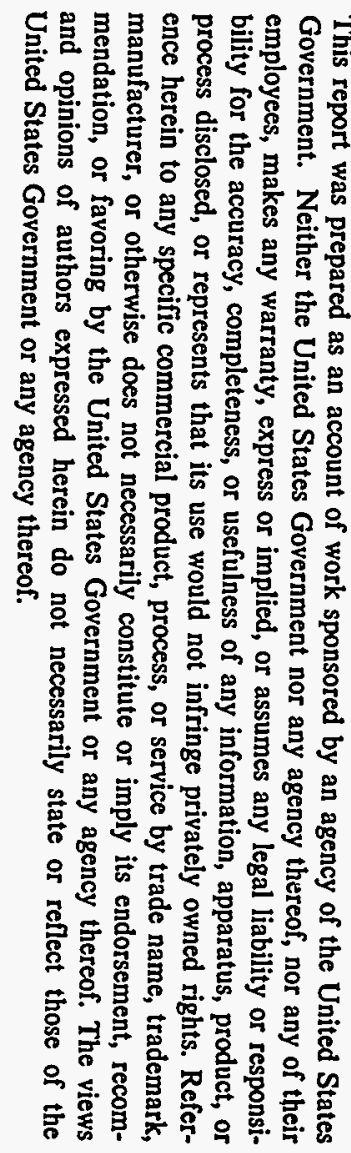

Kansas City DOE Support Office

911 Walnut Street, 14th Floor

Kansas City, MO 64106

(816) $426-4784$

(IA, KS, MO, NE)

New York DOE Support Office

26 Federal Plaza, Room 3437

New York, NY 10278

(212) 264-1021

(NJ, NY)

Philadelphia DOE Support Office

1880 JFK Boulevard, Suite 501

Philadelphia, PA 19103

(215) 656-6950

(DC, DE, MD, PA, VA, WV)

San Francisco DOE Support Office

1301 Clay Street, Room 1060 North

Oakland, CA 94612

(510) 637-1960

(AZ, CA, HI, NV;

Territories: AS, CM, GU, RP)

Seattle DOE Support Office

800 Fifth Avenue, Suite 3950

Seattle, WA 98104

(206) 553-1004

(AK, ID, OR, WA)

Notes: (1) Intergovernmental Panel on Climate Change.

Climate Change-the IPCC Scientific Assessment.

World Meteorological Organization/ United Nations

Environment Programme. Edited by J.T. Houghton,

G.J. Jenkins, and J.J. Ephraums, 1990.

(2) Air Emissions from Municipal Solid Waste

Landfills-Background Information for Proposed

Standards and Guidelines, EPA-450/3-90-011a

(NTIS) PB91-197061), Mnrch 1991.

This document was produced for the U.S. Department of Energy (DOE) by the National Renewable Energy Laboratory, a DOE national laboratory. The document was produced by the Technical Information Program, under the DOE Office of Energy Efficiency and Renewable Energy.

DOE/CH10093-322-Rev.2

DE94006897

Revised February 1995 Printed with a renewable-source ink on paper contanng at
least $50 \%$ wastepaper, including $20 \%$ postconsumer waste 